NIST Special Publication 1204

\title{
An Assessment of Typical Weather Year Data Impacts vs. Multi-year Weather Data on Net-Zero Energy Building Simulations
}

Joshua Kneifel

Eric O'Rear

This publication is available free of charge from: http://dx.doi.org/10.6028/NIST.SP.1204
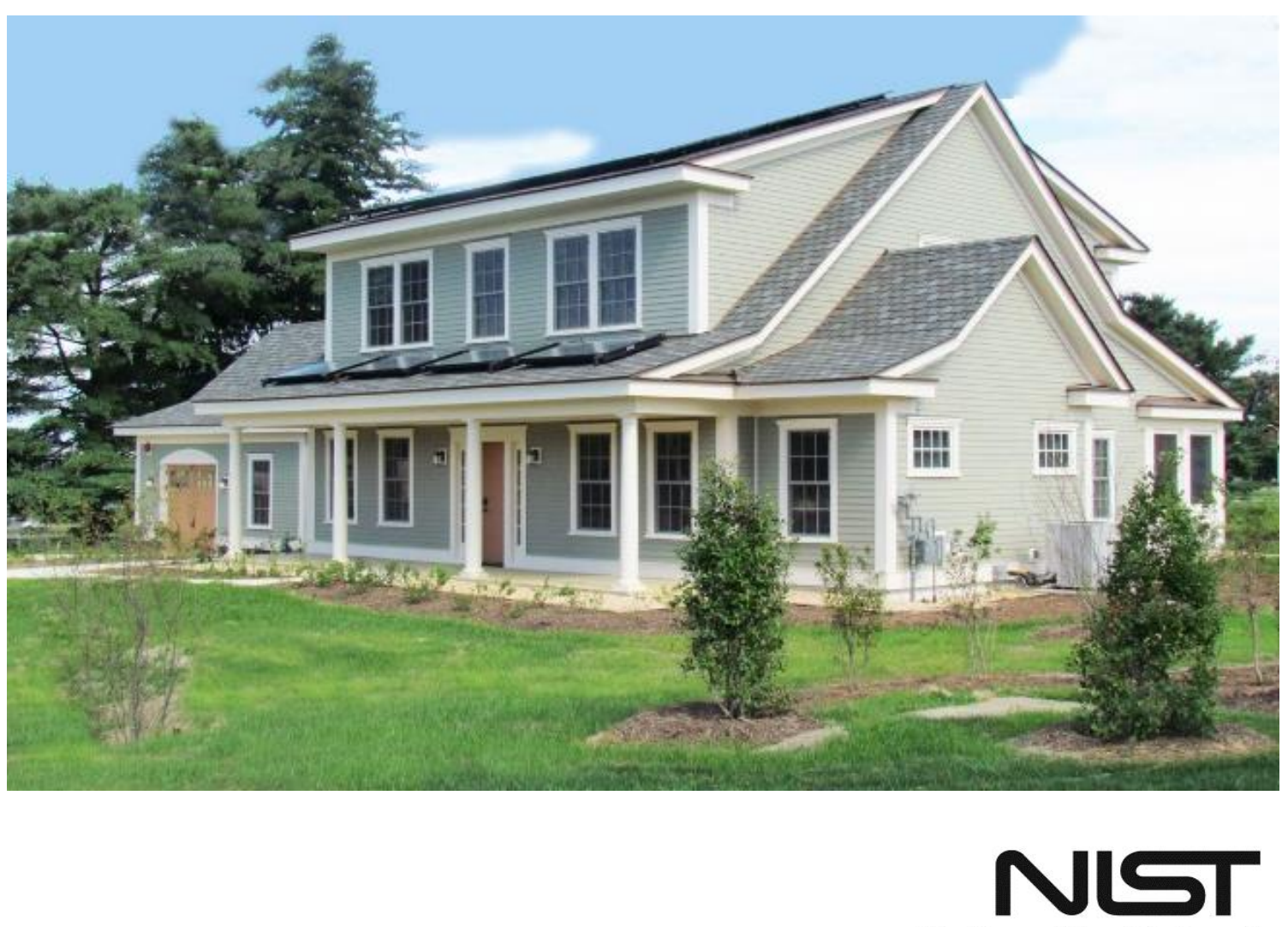

National Institute of Standards and Technology U.S. Department of Commerce 

NIST Special Publication 1204

\title{
An Assessment of Typical Weather Year Data Impacts vs. Multi-year Weather Data on Net-Zero Energy Building Simulations
}

\author{
Joshua Kneifel \\ Applied Economics Office \\ Engineering Laboratory \\ Eric O'Rear \\ Applied Economics Office \\ Engineering Laboratory
}

This publication is available free of charge from:

http://dx.doi.org/10.6028/NIST.SP.1204

January 2016

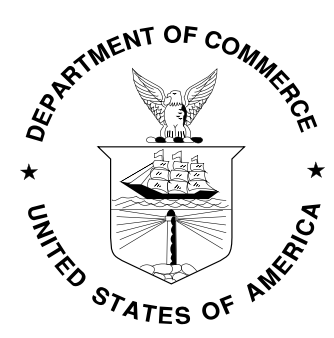

U.S. Department of Commerce

Penny Pritzker, Secretary

National Institute of Standards and Technology Willie May, Acting Under Secretary of Commerce for Standards and Technology and Director 
Certain commercial entities, equipment, or materials may be identified in this document in order to describe an experimental procedure or concept adequately. Such identification is not intended to imply recommendation or endorsement by the National Institute of Standards and Technology, nor is it intended to imply that the entities, materials, or equipment are necessarily the best available for the purpose.

National Institute of Standards and Technology Special Publication 1204

Natl. Inst. Stand. Technol. Spec. Pub. 1204, 45 pages (January 2016) CODEN: NTNOEF

This publication is available free of charge from: http://dx.doi.org/10.6028/NIST.SP.1204 


\begin{abstract}
This paper looks to contribute to the existing building simulation literature by examining the impacts of weather variability on annual household energy use and solar photovoltaic (PV) production for low-energy homes integrating renewable energy generation system(s) in their design. Using the U.S. Department of Energy's EnergyPlus v8.3 whole-building energy simulation program, we observe variability in the energy performance of a net-zero home across 34 different Actual Meteorological Year (AMY) weather files collected between 1980 and 2013 (U.S. Department of Energy (DOE) 2015). The simulated building design is based on the Net Zero Energy Residential Test Facility (NZERTF) developed by the National Institute of Standards and Technology. In addition to this, the simulation will be run with a local TMY3 weather file to evaluate how representative it is of "typical" weather conditions for the area, and if its use will result in accurate predictions of NZERTF energy performance.
\end{abstract}

\title{
Keywords
}

Energy efficiency; solar photovoltaics; net-zero; weather data; historical weather 


\section{Preface}

This study was conducted by the Applied Economics Office (AEO) in the Engineering Laboratory (EL) at the National Institute of Standards and Technology (NIST). The study is designed to observe the variability in the annual energy performance of the NIST Net-Zero Energy Residential Test Facility (NZERTF) over a period of 34 years. Additionally, the study seeks to evaluate how well the statistically-derived TMY3 weather file reflect average or "typical" weather conditions for the Gaithersburg, MD area.

\section{Disclaimers}

The policy of the National Institute of Standards and Technology is to use metric units in all of its published materials. Because this report is intended for the U.S. construction industry that uses U.S. customary units, it is more practical and less confusing to include U.S. customary units as well as metric units. Measurement values in this report are therefore stated in metric units first, followed by the corresponding values in U.S. customary units within parentheses. 


\section{Acknowledgements}

The authors wish to thank everyone for their advice and recommendations for the writing of this report, including Douglas Thomas and Dr. Robert Chapman of EL's Applied Economics Office, Matthew Boyd of EL's Energy and Environment Division, and Dr. Nicos S. Martys of EL's Materials and Structural Systems Division.

\section{Author Information}

Joshua D. Kneifel

Economist

National Institute of Standards and Technology

100 Bureau Drive, Mailstop 8603

Gaithersburg, MD 20899-8603

Tel.: 301-975-6857

Email: joshua.kneifel@ nist.gov

Eric G. O'Rear

Economist

National Institute of Standards and Technology

100 Bureau Drive, Mailstop 8603

Gaithersburg, MD 20899-8603

Tel.: 301-975-4570

Email: eric.orear@nist.gov 


\section{Contents}

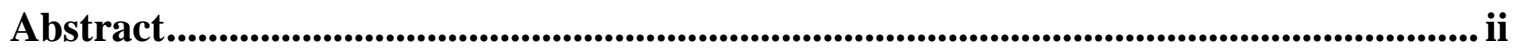

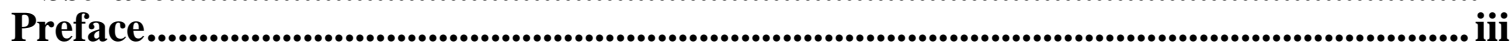

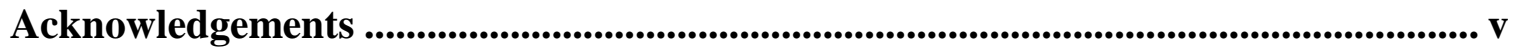

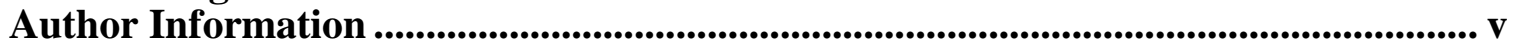

List of Acronyms ..............................................................................................................

1 Introduction..................................................................................................................... 1 1

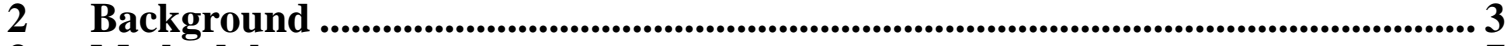

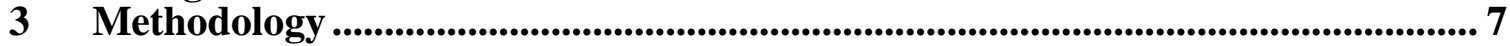

3.1 The NIST Net-Zero Residential Test Facility ….......................................... 7

3.2 Simulation model specifications and general assumptions ............................... 7

4 Results and Discussion........................................................................................... 11

4.1 Impacts of alternative weather profiles on NZERTF electricity consumption .. 11

4.2 Impacts of alternative weather profiles on the on-site solar photovoltaic electricity

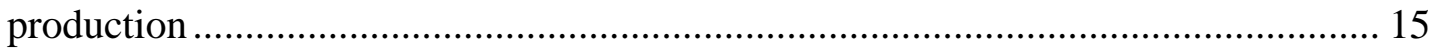

4.3 Impacts of alternative weather profiles on annual net electricity production .... 17

4.4 Impacts of alternative weather profiles on building HVAC system peak electricity demands 19

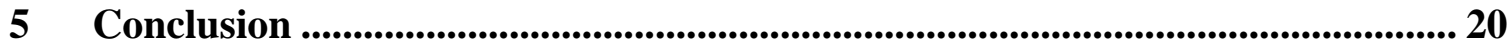

6 References ........................................................................................................................ 22

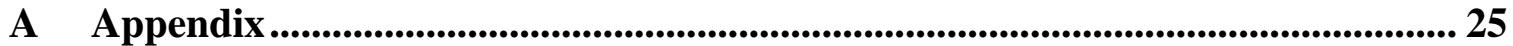




\section{List of Figures}

Figure 3-1 The NIST Net-Zero Energy Residential Test FacilityError! Bookmark not defined. Figure 4-1 Annual Household Electricity Use for AMY and TMY3 Files

(1980 through 2013)

Figure 4-2 Annual Electricity Usage for Household Heating and Cooling DemandsError!

Bookmark not defined.

Figure 4-3 Proportional Electricity use for Household Heating and Cooling Demands for TMY3 and AMY Files (1980 through 2013) ............................................................ 13

Figure 4-4 Total Number of HDD and CDD for AMY Files (1980 through 2013) .. Error! Bookmark not defined.

Figure 4-5 Histogram of Annual Household Electricity use for the TMY3 and AMY Files (1983 through 2013) 14

Figure 4-6 Annual NZERTF Solar PV Production and Global Horizontal Irradiance for TMY3 and AMY Files (1980 through 2013). .Error! Bookmark not defined. Figure 4-7 Average Global Horizontal Irradiance Measures for the TMY3 and Select AMY Weather Files 16

Figure 4-8 Histogram of Annual Solar PV Electricity Production for the TMY3 and AMY Files (1983 through 2013). Error! Bookmark not defined. Figure 4-9 Annual Net Electricity Production for TMY3 and AMY Files (1980 through 2013) 18

Figure 4-10 Histogram of Annual Net Electricity Production for the TMY3 and AMY Files (1983 through 2013). Error! Bookmark not defined. Figure 4-11 Annual Peak Electricity Demands for Building HVAC SystemError! Bookmark not defined. 


\section{List of Tables}

Table 3-1 NZERTF Building Specifications ..... 9 Table A-1 Annual Household Electricity Demands, Heating-based Electricity Demands, and Cooling-based Electricity Demands under each Weather File 25 Table A-2 Annual Household Electricity Demands, Solar PV Production, and Net Solar PV Production under each Weather File.

Table A-3 Peak Electricity Demands for the Building HVAC System under each Weather File 29 


\section{List of Acronyms}

\section{Acronym Definition}

$\mathrm{ACH} \quad$ air changes per hour

AEO Applied Economics Office

ARRA American Recovery and Reinvestment Act

ASHRAE American Society of Heating, Refrigerating and Air-Conditioning Engineers

BA Building America

BSC Building Science Corporation

CFA conditioned floor area

CFL compact fluorescent lamp

CFM cubic feet per minute

COP Coefficient of Performance

DHW Domestic Hot Water

E+ EnergyPlus

EERE Office of Energy Efficiency \& Renewable Energy

EIA Energy Information Administration

EL Engineering Laboratory

ELA effective leakage area

EPA Environmental Protection Agency

HRV Heat Recovery Ventilator

HSPF Heating Seasonal Performance Factor

HVAC Heating, Ventilation, and Air-Conditioning

IECC International Energy Conservation Code

NIST National Institute of Standards and Technology

NZERTF Net-Zero Energy Residential Test Facility

OC on center

PV photovoltaic

SEER Seasonal Energy Efficiency Ratio

SHGC Solar Heat Gain Coefficient

VT Visual Transmittance 


\section{Introduction}

As of 2014, commercial and residential buildings were responsible for $41 \%$ of total U.S. energy consumption (Energy Information Agency (EIA) 2015). The federal government through legislation such as the American Recovery and Reinvestment Act of 2009 (ARRA) has provided funds to energy efficiency and renewable energy research and investment in hopes of reducing the energy demands of residential buildings. Improving the energy efficiency of new residential construction can be a cost-effective method to help meet this goal (Kneifel 2011a). According to the USGBC Research Committee, a 30\% reduction in energy use relative to a more conventional house design can be achieved through various combinations of building envelope, water, lighting, and heating, ventilation, and air-conditioning efficiency measures. However, any building performance improvements of $50 \%$ or higher can only be secured if the aforementioned prescriptive measures are implemented in conjunction with a renewable energy system integrated into the household design (USGBC Research Committee 2008). System integration grows ever more important as the relative proportion of low-energy and net-zero energy buildings in new building stock increases. Buildings that are net-zero incorporate a wide variety of prescriptive energy efficiency measures to lower household energy consumption in conjunction with integration of renewable energy generation system(s) (e.g. solar photovoltaic [PV]) to provide a means for the home to produce energy on-site - leading to enough production to fully offset consumption over a year (Leckner and Zmeureanu 2011).

Researchers often utilize whole-building simulation models to predict the performance of individual building designs in a real-world environment (Crawley, Lawrie et al. 2000, Clarke 2001). Simulation results can then be used to make accurate, well-informed decisions on building specifications and the types of renewable energy systems to be integrated in the building design. Whole-building energy simulation programs, similar to other simulation models, are limited by their assumptions and the availability of accurate data (Maile, Fischer et al. 2007). Some programs consider the impacts of various external factors, such as local weather conditions on simulated building performance. Local weather conditions are often incorporated through the use of weather data captured in Actual Meteorological Year (AMY) and Typical Meteorological Year (TMY) files. AMY files are the actual weather data sets that have been collected over a given year. A TMY file for a location is developed using 15 to 30 years of hourly weather data for that specific location, and is assumed to be representative of the average climatic conditions (National Renewable Energy Laboratory (NREL) 1995). Reflected in these weather files is an array of information including solar irradiance and ambient temperature over a given year. In regards to building performance, the number of HDDs and CDDs impact the total energy consumed by the building to meet heating and cooling loads. Simulated energy production by an integrated solar PV system is directly impacted by measures of solar irradiance and ambient temperature. 
Simulation results generated using TMY weather files are interpreted as the performance of a building design under weather conditions that are "typical" for that location. The statistical approach used to compile a one-year TMY file, however, fails to consider any extreme weather anomalies that may have occurred (Dean 2010). The oversimplification of assumed localized weather conditions may produce some bias in the results and lead to inaccurate expectations of building performance.

A great deal of buildings literature examines the relationship between the uncertainty in local weather conditions and the energy performance of both commercial and residential buildings many of which compare the use of statistically-derived weather datasets to actual historical weather datasets in building simulation practices (Haberl, ONeal et al. 1995, Huang and Crawley 1996, Crawley 1998, Yang, Lam et al. 2008, Wang, Mathew et al. 2012, Hong, Chang et al. 2013). Researchers have gone a step further in many of these studies observing how varying levels of building energy-efficiency influence the impacts of weather uncertainty on energy use. Our work seeks to contribute to the existing literature by using a net-zero residential building simulation to analyze the impacts of weather variability on energy performance based on more than 30 years of historical data. Additionally, these results will then be compared to a simulation operating under "typical" weather conditions. For a net-zero building, its total energy use for a given year is roughly equal to the amount of renewable energy produced on site in that year; therefore, energy performance in our case will be evaluated based on annual energy consumption and on-site renewable energy generation. Using the U.S. Department of Energy's EnergyPlus v8.3 whole-building energy simulation program, we observe the variability in the energy performance of a net-zero residential dwelling across 34 different AMY weather files constructed using data collected between 1980 and 2013 (U.S. Department of Energy (DOE) 2015). The simulated net-zero design is based on the Net Zero Energy Residential Test Facility (NZERTF) developed by the National Institute of Standards and Technology (NIST) located in Gaithersburg, Maryland. Additionally, the simulation is run with the most recent TMY3 weather file from the KGAI weather station for the purpose of determining how well it represents "typical" weather conditions for Gaithersburg, MD, and whether its use can accurately provide insight on the projected energy performance of the NZERTF. 


\section{Background}

The rising popularity of low-energy and net-zero homes in the residential housing market has led to an upsurge in the demand for solar energy generation technologies. Homeowners anticipate recouping large levels of energy cost savings by relying on solar PV to offset some of their grid usage. Development of whole-building simulation programs has given building designers the ability to evaluate the impacts of solar PV integration on the overall energy performance of their designs, specific to weather conditions appropriate for their desired location. However, there can be a great deal of uncertainty in solar generation in response to variability in local climate conditions that is not accounted for by these programs.

Operating building simulation programs requires data on meteorological inputs for a specific location. Actual Meteorological Year (AMY) databases provide these inputs for a given location. However, weather data captured in AMY files vary from year to year and make it difficult to determine what the average simulated building performance will be. Typical Meteorological Year (TMY) databases were developed as a solution to this problem. The U.S. Department of Energy's National Renewable Energy Laboratory (NREL) first developed TMY files in 1981, serving as a representation of the average weather conditions for a specific location. Files are created by looking at 15 to 30 years of hourly weather data, generally collected by a local weather station, and include data on various weather characteristics such as solar radiation and temperature, for a designated location. Statistical methods are then used to select each of the twelve months considered to be "typical" for that location (Weather Analytics 2014). Subsequent iterations of TMY data were created based on weather data collected for different periods. The Typical Meteorological Year version 2 (TMY2) files were developed using weather station data from 1961 to 1990 and is available for 239 locations in the U.S. (National Renewable Energy Laboratory (NREL) 1995). The latest version (TMY3) covers only 15 years (1991 - 2005) and includes weather information for more than 1,400 sites in the U.S. It also includes information on new variables such as precipitation (National Renewable Energy Laboratory (NREL) 2008).

Although the TMY files help to generalize weather conditions and simplify the forecasting process, there are some disadvantages associated with their use. For one, methods used to construct them disregard periods of extreme weather conditions or anomalies. NREL relies on the empirical Sandia method to develop their TMY3 files. The approach disregards atypical weather anomalies occurring during the set of years being considered. Therefore, any resulting decisions on building equipment for energy-efficient designs that are directly influenced by simulation results using these files may or may not account for strained used of the equipment in the case of brief periods of atypical weather conditions. Secondly, files may be developed using fewer than 15 years of data. NREL uses 15 years of data when constructing TMY3 files. A lack of 15 years of consistent data in some locations could limit the robustness of the generated data. In some instances, a lack of recent available data may lead to TMY3 files being constructed 
based on much older data (Weather Analytics n.d.). In constructing TMY files the data generally comes from airport data collection stations which means that the further away a simulated building's location is from the collection site, the less valid the assumptions of local weather conditions will be. Each of these disadvantages could potentially lead to a bias in the simulation results, with modeled performance being over- or underestimated.

Issues regarding the use of TMY files in practice have been observed in modeling wholebuilding energy consumption for commercial buildings (Huang and Crawley 1996, Crawley 1998, Wang, Mathew et al. 2012, Hong, Chang et al. 2013). In their work comparing the impacts of TMY3 data and actual collected weather data spanning 30 years on energy consumption and peak electricity demands for three prototype commercial buildings (office) at two levels of efficiency across the 17 ASHRAE climate zones, authors Hong, Chang et al. (2013) found that measured consumption ranged between $-28 \%$ and $15 \%$. They decided that the lack of agreement between the series of weather files is largely attributed to the TMY3 file not accurately capturing average weather conditions in each location. Similarly, Wang et al. (2012) finds that annual energy usage can vary between $-4.0 \%$ to $6.1 \%$ when comparing the simulated office building's annual consumption under TMY3 weather conditions to consumption levels estimated using 10 years to 15 years of historical data across four U.S. cities. A broader study is conducted by Crawley (1998) in which he looks at the uncertainty in simulated energy use for commercial buildings linked to weather variability across multiple datasets. Using the DOE-2 1E building simulation model, he compares the impacts of different "typical" weather datasets to 30 years of actual hourly weather data captured in the SAMSON (Solar and Meteorological Surface Observational Network) weather dataset on the simulated annual energy consumption and costs, and annual peak electricity demand for a prototype office building across eight different locations. He discovers that the annual energy consumption will vary from $-11 \%$ to $7 \%$ relative to the derived average consumption using the SAMSON dataset. Approximately half of the variation is observed with annual energy costs and peak electricity demand. Of the six typical datasets studied, the TMY2 weather data resulted in the least amount of variation in many of the locations, suggesting that the methodology used in formulating the weather file can provide accurate simulation results relative to other methodologies. This fact, however, is sensitive to the underlying data used and the location being considered.

Similarly, Huang (1998) uses prototypical residential building simulations to compare the simulated heating and cooling loads under different weather datasets capturing average weather conditions to that of a 30-year average. He finds that heating and cooling energy consumption using the TMY2 weather data falls within $5 \%$ of the long-term averages. 
Similar to building simulation models, solar PV energy production forecasting tools require the meteorological inputs of TMY files, also making them susceptible to a degree of uncertainty. Williams and Kerrigan (2012) suggest that TMY data - in particular the most recent TMY3 dataset - can provide an adequate representation of solar conditions, potentially lowering the anticipated risk associated with using typical weather data to forecast production. Other analyses (Cameron, Boyson et al. 2008, Dean 2010, Yimprayoon and Navvab 2011) suggest some level of caution, stressing the likelihood of noticeable differences in production outputs whenever actual weather conditions are considered in place of typical ones. In comparing the TMY2 weather profile constructed over a 30-year period to an alternative weather profile depicting the "average" weather conditions over the same period, Dean (2010) discovers that the TMY2 data is not representative of a central tendency in the data, and appears to be an outlier when compared to the average weather file. He goes on to show that use of the PVWatts solar PV production tool in conjunction with the TMY2 data regularly overestimates monthly production by $6 \%$ over the average, and forecasted TMY 2 production exceeds more than $90 \%$ of the estimated production based on historical data. Yimprayoon and Navvab (2011) discovered that the use of historical data in forecasting solar PV production helps to showcase a large degree of production uncertainty related to variations in annual weather conditions not captured by the statistically derived TMY3 data sets. Other authors such as Cameron et al. (2008) note that even though these discrepancies do exist when using TMY data, the output from most PV production models when using these datasets will lie within $+/-5 \%$ of actual production.

Some of the inconsistencies exhibited by TMY weather files are attributed to the methods in which they are constructed and/or the length of historical data used in constructing the files (Janjai and Deeyai 2009, Donghyun, Yu Joe et al. 2010). A study completed by Janjai and Deeyai (2009) on solar PV production in Thailand reveals the degree of uncertainty that exists across the Sandia, Danish, and the Festa \& Ratto TMY data generation methods. Generated TMY data points such as temperature, relative humidity, and wind speed were well predicted across all three approaches when compared to actual measurements. However, significant variation in solar radiation estimates result in a large variation in the predicted electricity output for an installed system in that region. Despite the Sandia method being found to be more preferable to the others, the degree of variation in production is acceptable for the purposes of forecasting solar PV production.

The above literature suggests that when conducting building simulations, there is likely to be differences in simulated energy use and production when using typical year weather data to local weather conditions in place of multi-year historical data. There is also evidence of energy performance uncertainty associated with local weather variability. With evidence of a changing global climate and growing interest in high efficiency homes, it is imperative that building designers recognize that the use of weather datasets like TMY3 could lead to simulation results that fail to reflect accurate building responses to local weather. It is also important recognize the 
degree of consumption and production uncertainty present given the likelihood of varying weather conditions from year to year. 


\section{Methodology}

\subsection{The NIST Net-Zero Residential Test Facility}

The NIST's NZERTF is located on the NIST main campus in Gaithersburg, Maryland. The twostory, four-bedroom house was initially constructed to show that a residential home design could be net-zero and have the "look and feel" of a typical home in the area (Pettit and Gates 2014). It has approximately $251.7 \mathrm{~m}^{2}\left(2709 \mathrm{ft}^{2}\right)$ of total conditioned floor area and was designed to be roughly $60 \%$ more energy-efficient than newly constructed homes in the area built according to the 2012 International Energy Conservation Code (IECC). Additionally, a $10.2 \mathrm{~kW}$ solar PV system was installed on the roof of the NZERTF to produce more electricity than is consumed over a given year. The facility serves as an on-site laboratory (Figure 1). During its first year of operation (July 2013 through June 2014), the house exceeded net-zero energy performance with a surplus of $596 \mathrm{kWh}$, which was enough electricity to fuel an electric vehicle for close to $2253 \mathrm{~km}$ (1400 miles) (Kneifel, Payne et al. 2015).

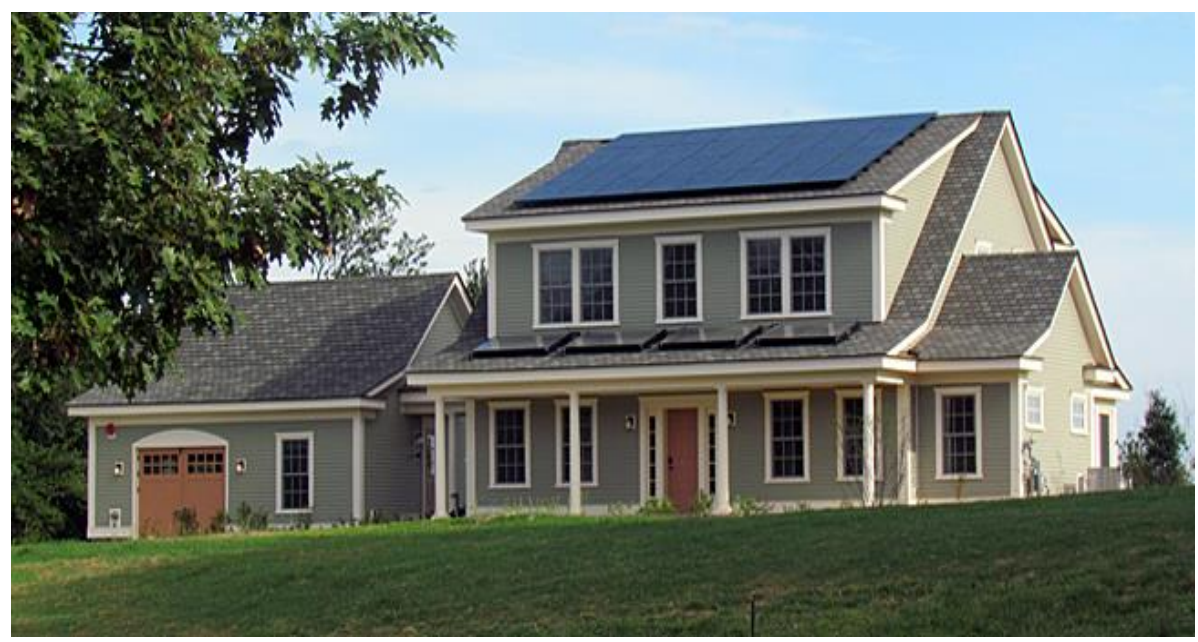

Figure 3-1: The NIST Net-Zero Energy Residential Test Facility

\subsection{Simulation model specifications and general assumptions}

Evaluation of the energy performance of any building design requires the use of whole-building simulation software. This study utilizes the results from the EnergyPlus 8.3.0 whole-building energy simulation program to observe the yearly energy performance of the NZERTF (U.S. Department of Energy (DOE) 2015). Operation of these programs require a number of general assumptions and user-defined specifications, such as data best representative of local weather conditions, time step designations, and run periods. The program also requires the specifications of the simulated building design. 
Energy use based on alternative assumptions for local weather conditions is estimated with EnergyPlus by using the third iteration of the local TMY (TMY3) weather file and the AMY weather files spanning 1980 through 2013 for the KGAI weather station located less than seven miles from the NIST campus (Weather Analytics 2014, Kneifel, Payne et al. 2015). This weather station was selected because it is the nearest data collection station to the NZERTF facility, and has weather data spanning more than fifteen years (the minimum number of years of data used to develop a TMY weather file).

In addition to weather data, the EnergyPlus software requires the user to select a specific run period and time step. A run period is the days of the year the simulation will run. The time step is the frequency at which the model runs the simulation. A one-year run period is selected since we are observing the impacts of alternative weather conditions on annual energy use and production. A one minute time-step is also chosen since the assumed length of some household activities (e.g. hot water use by the sink) are modeled in one minute increments, and the use of a one minute time step allows us to more accurately capture system operation and the resulting energy consumption (Kneifel 2012). ${ }^{1}$

The "validated" NZERTF simulation used in this analysis was designed according to the postdemonstration phase specifications of the facility to mimic actual performance specifications ${ }^{2}$. Table 3-1 describes the most recent building specifications/energy efficiency measures incorporated into the NZERTF simulation design.

\footnotetext{
${ }^{1}$ Weather files are based on hourly data and are interpolated for the shorter simulation model timestep.

${ }^{2}$ Adjustments to the initial NZERTF simulation within EnergyPlus were made based on a comparison of the predemonstration simulated energy performance and the actual measured performance of the home at the end of its demonstration phase in June 2014. See Kneifel, Payne et al. (2015) for more details on the adjustments made to the NZERTF simulation.
} 
Table 3-1: NZERTF Building Specifications

\begin{tabular}{|c|c|c|}
\hline Building Category & Specifications & Details \\
\hline Windows & $\begin{array}{l}\text { U-Factor } \\
\text { SHGC } \\
\text { VT }\end{array}$ & $\begin{array}{c}1.14 \mathrm{~W} / \mathrm{m}^{2}-\mathrm{K}\left(0.20 \mathrm{Btu} / \mathrm{h}^{*} \mathrm{ft}^{2}-\mathrm{F}\right) \\
0.25 \\
0.40\end{array}$ \\
\hline $\begin{array}{l}\text { Framing and } \\
\text { Insulation }\end{array}$ & $\begin{array}{l}\text { Framing } \\
\text { Exterior Wall } \\
\text { Basement Wall** } \\
\text { Roof }\end{array}$ & $\begin{array}{c}5.1 \mathrm{~cm} \mathrm{X} 10.2 \mathrm{~cm}-40.6 \mathrm{~cm} \mathrm{OC}(2 \text { in } \mathrm{X} 6 \text { in }-24 \text { in } \mathrm{OC}) \\
\mathrm{R}_{\mathrm{SI}^{-}}-3.5+4.2(\mathrm{R}-20+24 *) \\
\mathrm{R}_{\mathrm{SI}^{-}}-3.9\left(\mathrm{R}-22^{*}\right) \\
\mathrm{R}_{\mathrm{SI}^{-}}-9+5.3\left(\mathrm{R}-45+30^{*}\right)\end{array}$ \\
\hline Infiltration & $\begin{array}{l}\text { Air Change Rate } \\
\text { Effective Leakage } \\
\text { Area }\end{array}$ & $\begin{array}{c}0.63 \mathrm{ACH}_{50} \\
1^{\text {st }} \text { Floor }=132.6 \mathrm{~cm}^{2}\left(20.6 \mathrm{in}^{2}\right) \\
2^{\text {nd }} \text { Floor }=120.9 \mathrm{~cm}^{2}\left(18.7 \mathrm{in}^{2}\right)\end{array}$ \\
\hline Lighting & $\begin{array}{l}\% \text { of Efficient } \\
\text { Lighting }\end{array}$ & $100 \%$ efficient built-in fixtures \\
\hline HVAC & $\begin{array}{l}\text { Heating/Cooling } \\
\text { Outdoor Air } * * *\end{array}$ & $\begin{array}{c}\text { Air-to-air heat pump (SEER 15.8/HSPF 9.05) } \\
\text { Separate HRV system }\left(0.04 \mathrm{~m}^{3} / \mathrm{s}\right)\end{array}$ \\
\hline Domestic Hot Water & $\begin{array}{l}\text { Water Heater } \\
\text { Solar Thermal }\end{array}$ & $\begin{array}{l}50 \text { gallon heat pump water heater (COP } 2.36) \\
2 \text { panel, } 80 \text { gallon solar thermal storage tank }\end{array}$ \\
\hline Solar PV System & System size & $10.2 \mathrm{~kW}$ \\
\hline \multicolumn{3}{|c|}{ * Interior + Exterior R-Value } \\
\hline *** Minimum outdo & requirements a & on ASHRAE 62.2-2010 \\
\hline
\end{tabular}

The building envelope of the NZERTF is constructed to be "tighter" than identical homes built according to the 2012 IECC with regards to framing, insulation, windows, and air leakage. It is constructed using $5.1 \mathrm{~cm} \mathrm{X} 15.2 \mathrm{~cm}-61.0 \mathrm{~cm}$ (2 in X 6 in -24 in) on center (OC) framing ("advanced framing") as opposed to the traditional $5.1 \mathrm{~cm} \mathrm{X} 10.2 \mathrm{~cm}-40.6 \mathrm{~cm}$ (2 in X 4 in -16 in) OC framing. Thicker framing decreases the amount of wood used in framing the house, while allowing for more insulation within the wall cavity, potentially improving the overall thermal

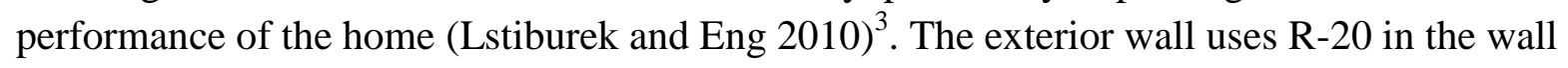
cavity plus an additional R-24 of rigid insulation. The interior of the basement wall uses R-10

\footnotetext{
${ }^{3}$ Use of $2 \times 6$ wood framing at 24-inch centers reduced the amount of lumber needed for construction (board-feet) by 5 to $10 \%$, and provides $60 \%$ more cavity insulation.
} 
plus an additional R-12 of rigid insulation. Construction of the roof includes R-45 insulation in the rafters with rigid insulation R-30 added to the exterior of the roof.

The U-Factor, Solar Heat Gain Coefficient (SHGC), and the Visible Transmittance (VT), are used in the simulation to specify the fenestration surface construction materials for the windows. The values listed in the table are based on minimum requirements specified in the 2012 IECC and the Building Science Corporation (BSC) window specifications (Building Science Corportation (BSC) 2009).

The measure of air tightness or infiltration for the NZERTF is characterized by the air changes per hour at $50 \mathrm{~Pa}\left(\mathrm{ACH}_{50}\right)$ using a blower door test, which was measured at 0.63 . The air changes per hour was converted into effective leakage area (ELA) and split between the first and second floor of the simulated design based on fraction of volume because the use of ELA leads to more accurate simulation results (Kneifel, Payne et al. 2015).

All electrical and mechanical systems in the house are more energy-efficient than federal requirements. All light fixtures in the NZERTF are high efficiency with the use of compact fluorescent (CFL), linear fluorescent, and light emitting diode (LED) bulbs. The Heating, Ventilation, and Air-Conditioning (HVAC) system uses a high-efficiency heat pump to meet the heating and cooling loads of the home, while incorporating a heat recovery ventilator (HRV) operating year-round to meet any mechanical ventilation requirements. The household domestic hot water (DHW) system includes a 50-gallon heat pump water heater with a coefficient of performance of 2.6 and an electric back-up with a thermal efficiency of 0.98 . It also uses two solar thermal panels and an 80-gallon storage tank to preheat water entering the heat pump water heater. The on-site solar PV system is a $10.2 \mathrm{~kW}$ system, which was the largest system that could be installed on the top roof. For additional details on the NZERTF simulation design specifications and general assumptions, refer to Kneifel, Payne et al. (2015). 


\section{Results and Discussion}

Weather-related factors such as the total number of heating degree-days, cooling degree-days, and solar irradiance can strongly impact the overall performance of a building. Researchers commonly rely on TMY weather files to simulate the building's energy performance under "typical" weather conditions that are representative of that building's assumed location.

However, the use of a single TMY weather file cannot account for the significant variations and trends realized in weather patterns from year-to-year. In this section, we will discuss the impacts of weather variability on the energy performance of NIST's NZERTF using 34 years' worth of actual weather (AMY files). Additionally, we will examine how accurately the TMY3 weather file represents "typical" weather conditions for the given location.

\subsection{Impacts of alternative weather profiles on NZERTF electricity consumption}

Figure 4-1 shows annual electricity consumption by the NZERTF from 1980 through 2013, the trend line for consumption based on the AMY files (red), and annual consumption based on TMY3 weather conditions (dashed orange). Annual household electricity consumption varies from $11300 \mathrm{kWh}$ in 2001 to $12983 \mathrm{kWh}$ in 1989, with a long-term average downward trend of $13.4 \mathrm{kWh} / \mathrm{yr}$. Use of the TMY3 weather file results in $11783 \mathrm{kWh}$ of annual electricity consumption, and an average percent difference of $-3.1 \%$. Use of the TMY 3 weather file does not appear to be representative of average conditions as it leads to an underestimation of total electricity use.

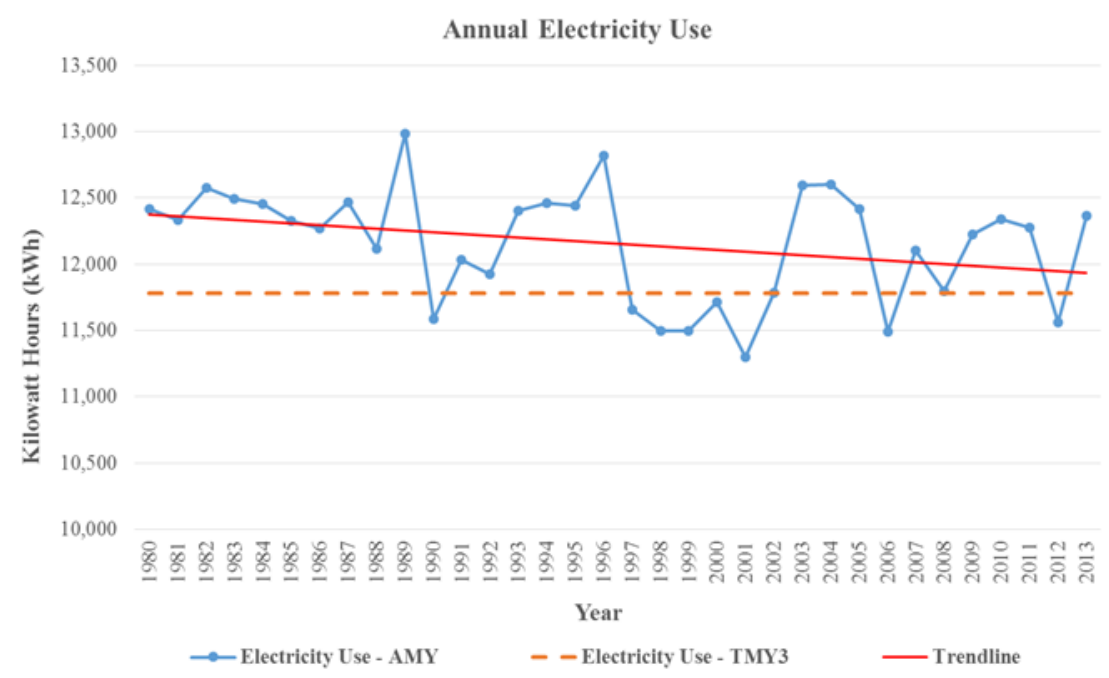

Figure 4-1: Annual Household Electricity Use for AMY and TMY3 Files (1980-2013)

The noticeable spikes in electricity use in years 1989 and 1996, along with the downward trend in consumption across the AMY files, are associated with variability in annual heating and cooling loads. Figure 4-2 displays the total kilowatt-hours of electricity used to satisfy household heating and cooling loads given each weather file. On average, electricity demands associated 
with heating trend downward, and cooling related electricity use trends upward. Indicated by differences in the slopes of the two trend lines, simulated household electricity demands for heating are more responsive $(24.6 \mathrm{kWh}$ /year) to changes in AMY file assumptions than cooling $(12.3 \mathrm{kWh} / \text { year })^{4}$. With the state of Maryland being located in a moderately temperate climate that is heating-driven and growing warmer on average each year, the NZERTF will marginally continue swapping their heating demands for more cooling. Under typical weather conditions, heating- and cooling-related electricity consumption is below the 34-year averages. In the case of cooling, it is above the 34-year average. The results once again highlight the inability of the TMY3 to accurately reflect average weather conditions for the area.

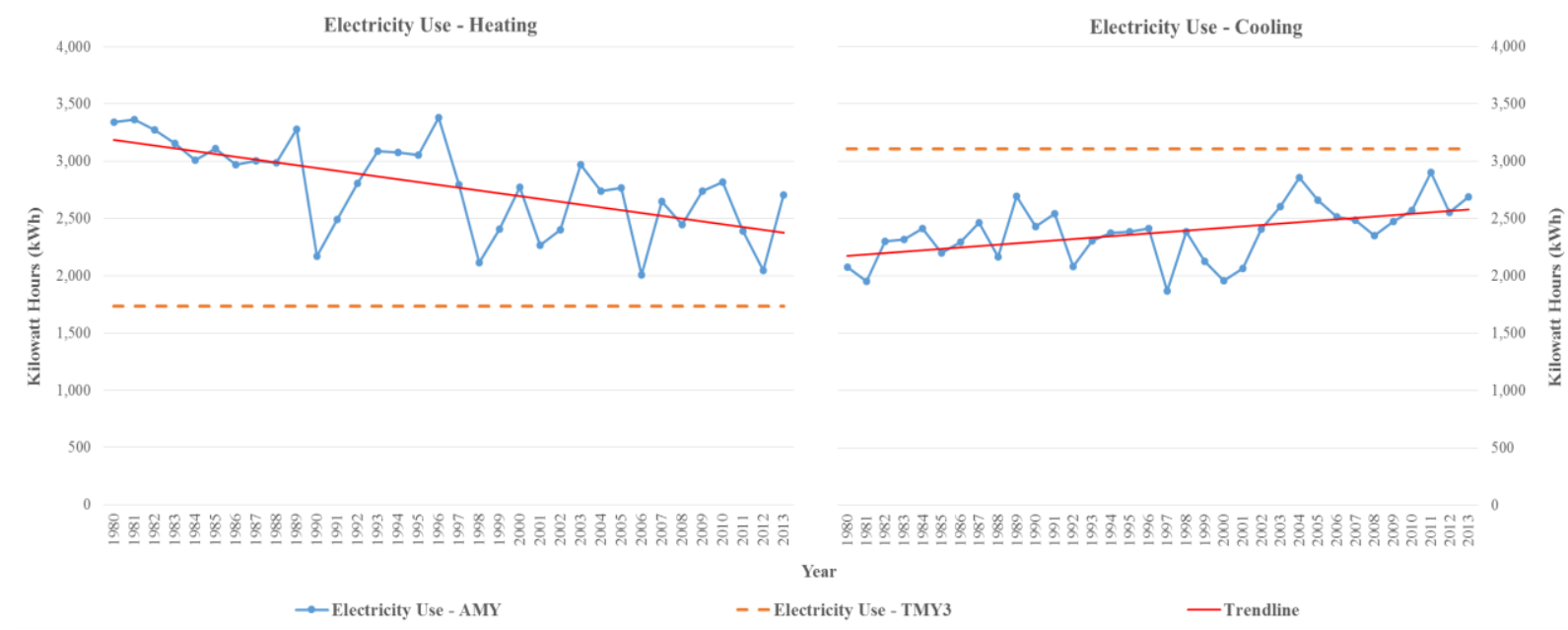

Figure 4-2: Annual Electricity Usage for Household Heating and Cooling Demands

Figure 4-3 displays the electricity consumed each year to meet the simulated heating and cooling loads. In the case of the 1989 and 1996 AMY weather files, there are spikes in annual electricity demands (Figure 2). Figure 4-3 below suggests that in these years a combination of above average heating and cooling loads are responsible for the consumption spikes. In years such as 1990 and 2006, above average cooling loads are outweighed by below average heating loads, leading to smaller overall electricity demands relative to the alternative weather files.

\footnotetext{
${ }^{4}$ Data for Figure 4-2 can be found in Table A-1 of the Appendix.
} 


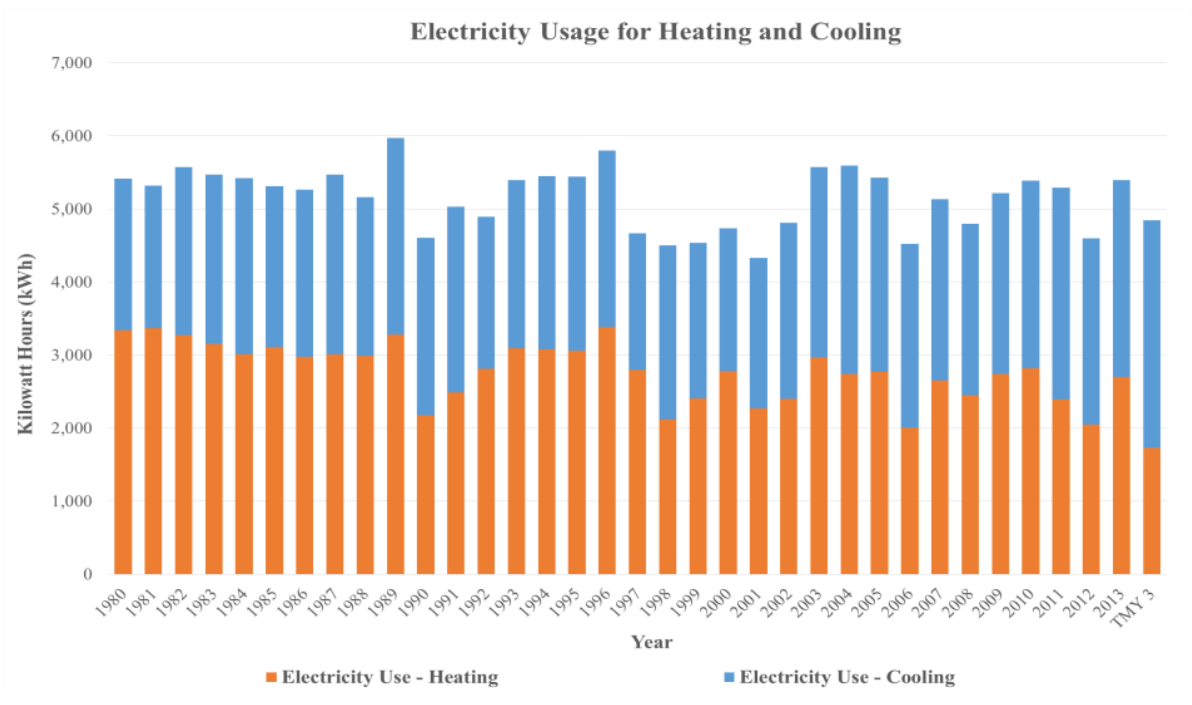

Figure 4-3: Proportional Electricity use for Household Heating and Cooling Demands for TMY3 and AMY Files (1980-2013)

Based on the results in Figure 4-2 and Figure 4-3, the average decline in heating loads and average growth in cooling loads suggest that the overall local climate captured by the AMY files is becoming warmer over time. A more accurate indicator of changing climate conditions is the variation in the number of HDDs and CDDs over time. Figure 4-4 shows the total number of HDDs, CDDs, and their sum across all 34 AMY files. From 1980 to 2013, there is a slight downward trend in total HDDs. In the case of CDDs, a slightly upward trend is revealed. Fewer HDDs and more CDDs reveal a slowly changing climate that is growing warmer over time. This trend combined with the higher efficiency of the cooling equipment relative to the heating equipment could lead to continued reductions in energy use in the near future. Average weather conditions captured by the TMY3 file reflect a higher number of CDDs relative to HDDs; however, the existing process used to derive the TMY3 weather conditions will continue to produce results that understate the impacts of local weather conditions on household energy performance.

It is not clear what is driving the total amount of HDDs and CDDs in periods where there is a spike or a large drop in electricity demands. These anomalies may best be explained by natural climatic events. For example, the spike in electricity consumption given 2003 weather conditions is again primarily associated with larger heating loads. This weather year coincides with a moderate El Niño year, in which winters in the Southeast during this period are characterized as being cooler and wetter, which could explain larger heating loads and higher electricity demands. The underlying data does not provide enough information to discern if and what climatic occurrences are at play. However, it is important to acknowledge the possibility of some existing correlation. 


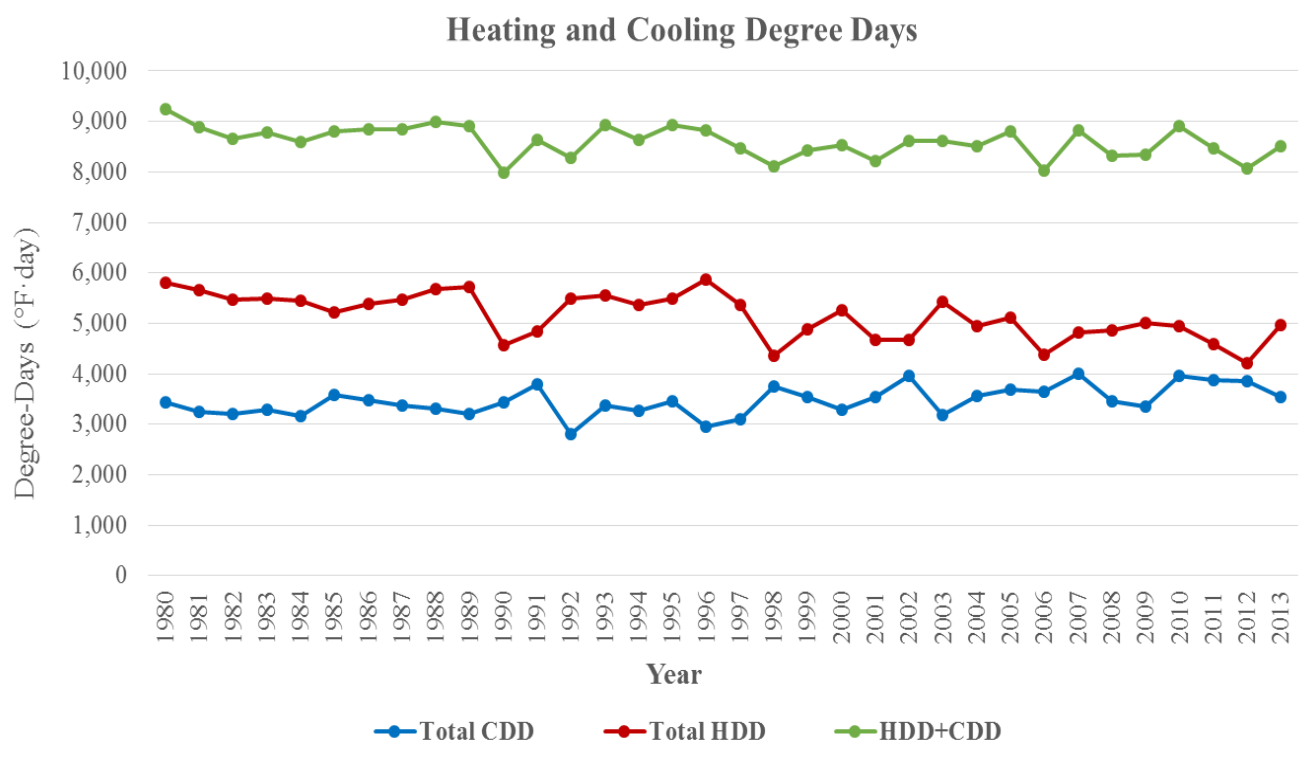

Figure 4-4: Total Number of HDD and CDD for AMY Files (1980 through 2013)

Assuming typical weather conditions, total electricity use (11 $783 \mathrm{kWh})$ is roughly $3 \%$ and $4 \%$ below the average (12 $157 \mathrm{kWh})$ and median (12 $300 \mathrm{kWh})$ consumption levels, respectively, for AMY files 1983 through 2013. Figure 4-5 shows the distribution of annual electricity use for all 34 AMY files as well as indicators of the median and TMY3 consumption levels. The distribution is left skewed implying that majority of the predicted consumption is concentrated to the right of the average.

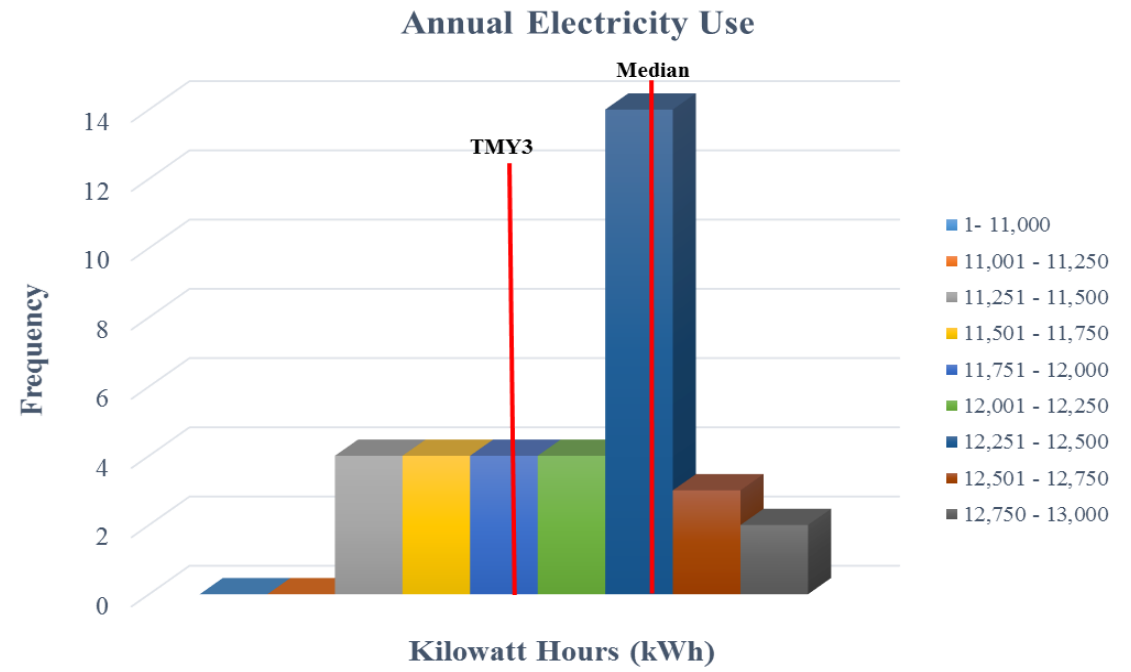

Figure 4-5: Histogram of Annual Household Electricity Use for the TMY3 and AMY Files (1983 through 2013) 


\subsection{Impacts of alternative weather profiles on the on-site solar photovoltaic electricity production}

The NZERTF design is setup to operate solely on electricity, drawing its power from both the local utility and the electricity generated from the on-site $10.2 \mathrm{~kW}$ solar PV system.

Figure 4-6 displays both annual solar PV electricity production and Global Horizontal Irradiance (GHI) measurements for all 34 AMY weather files and the TMY3 weather file. The least production $(13053 \mathrm{kWh})$ occurs under weather conditions captured by the 2003 AMY weather file. The largest (14931 kWh) is realized under 2010 conditions. Assumptions of typical weather conditions lead to an overestimation of solar electricity generation with an annual production of roughly $15131 \mathrm{kWh}$. Global Horizontal Irradiance (GHI) is the total amount of shortwave radiation received from the sun by a surface lying horizontal to the ground. GHI measures include both the Diffuse Horizontal Irradiance (DHI) and the Direct Normal Irradiance (DNI) (National Renewable Energy Laboratory (NREL) 2014). Solar electricity production is largely a function of the level of solar radiation to which the system is exposed (Ganguli and Singh 2010). Figure 4-6 confirms this relationship by revealing that periods of lower irradiance coincide with lower levels of PV production, and higher irradiance levels coincide with greater production. A visible upward trend in both annual production and GHI levels suggests that, on average, more solar electricity generation by the home can be expected as average local solar radiation levels continue to increase over time. Data on the home's annual PV production can be found in Table A-2 of the Appendix.

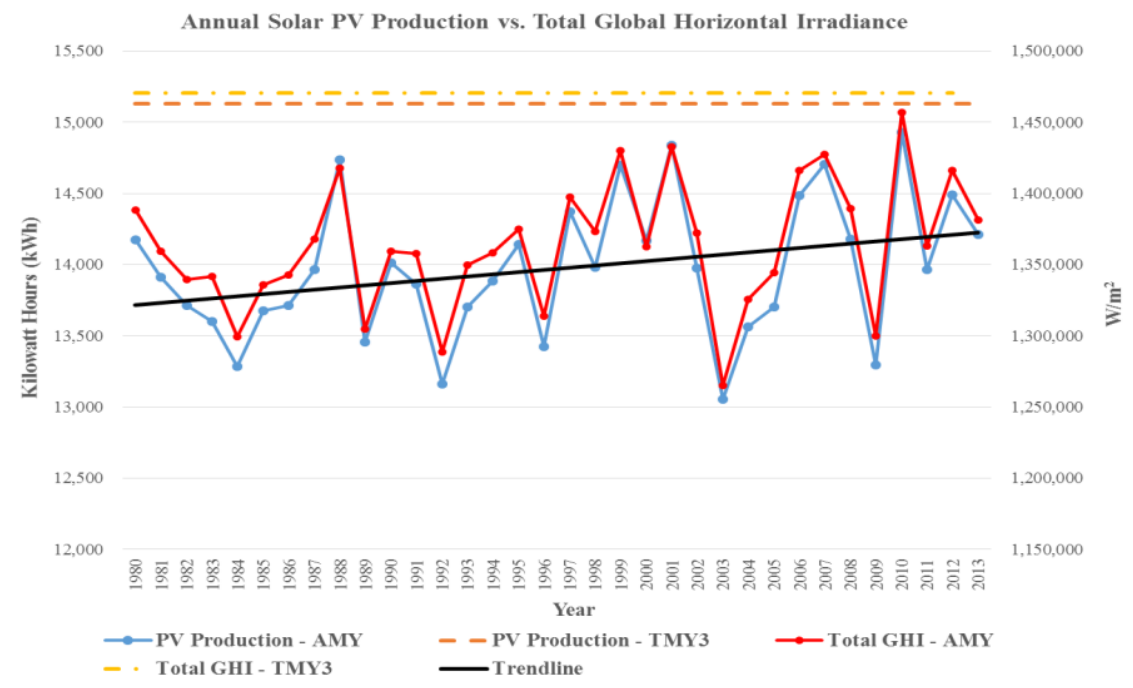

Figure 4-6: Annual NZERTF Solar PV Production and Global Horizontal Irradiance for TMY3 and AMY Files (1980 through 2013)

The noticeably higher solar electricity generation predicted using TMY3 data are largely explained by the inflated solar irradiance levels captured by the weather file. Examining the monthly GHI averages helps to further illustrate any variations between the TMY3 and AMY 
irradiance measures. Figure 4-7 shows the average GHI levels for the TMY3 dataset and four AMY datasets (1980, 1988, 2010, and 2013). The four datasets were selected based on having the highest average measured total global horizontal irradiance levels of all the 34 AMY files. The TMY3 irradiance levels are consistently higher than the actual collected data during the late spring/summer months (April through September). During the late fall and winter months, TMY3 average GHI levels are relatively comparable. Given the relationship between PV production and solar irradiance, it is clear that that above average "typical" solar irradiance values will likely cause an overestimation of solar renewable energy generation.

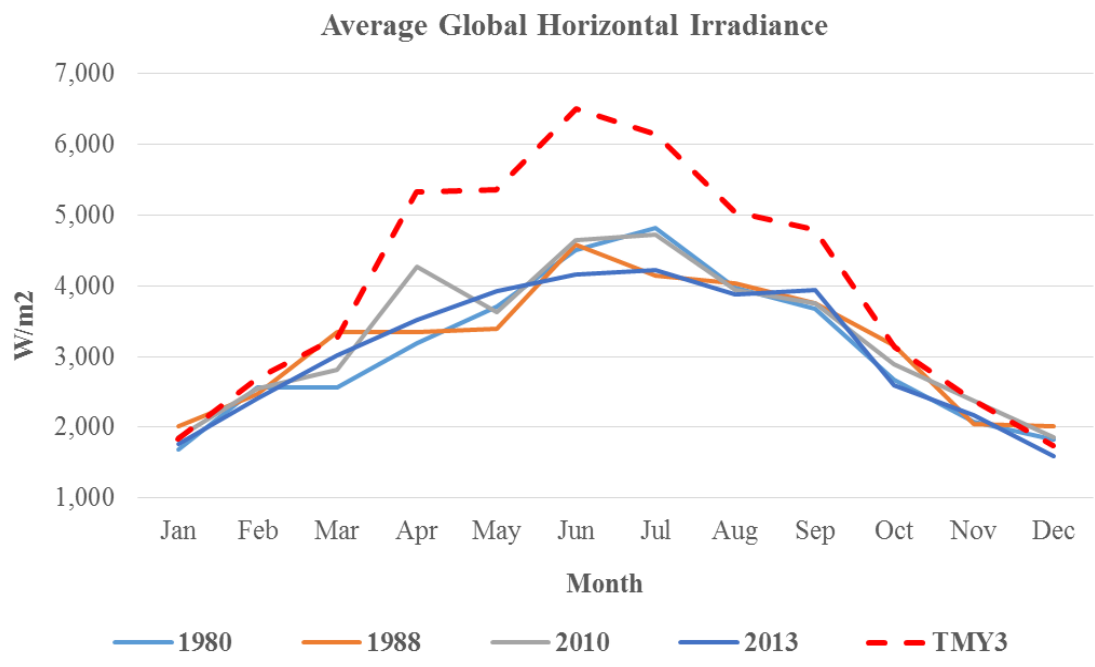

Figure 4-7: Average Global Horizontal Irradiance Measures for the TMY3 and Select AMY Weather Files

A histogram of solar PV electricity production developed based on the 35 simulations is shown in Figure 4-8. The average (not pictured), median, and mode (not pictured) production levels are $13972 \mathrm{kWh}, 13965 \mathrm{kWh}$, and $13703 \mathrm{kWh}$, respectively. All three measures fall within the $13701 \mathrm{kWh}$ to $14050 \mathrm{kWh}$ bin range. Given that TMY3 production falls at the top end of the distribution (15 $131 \mathrm{kWh}$ or $8 \%$ above the average AMY production), it is very unlikely that actual yearly production will achieve these levels. 


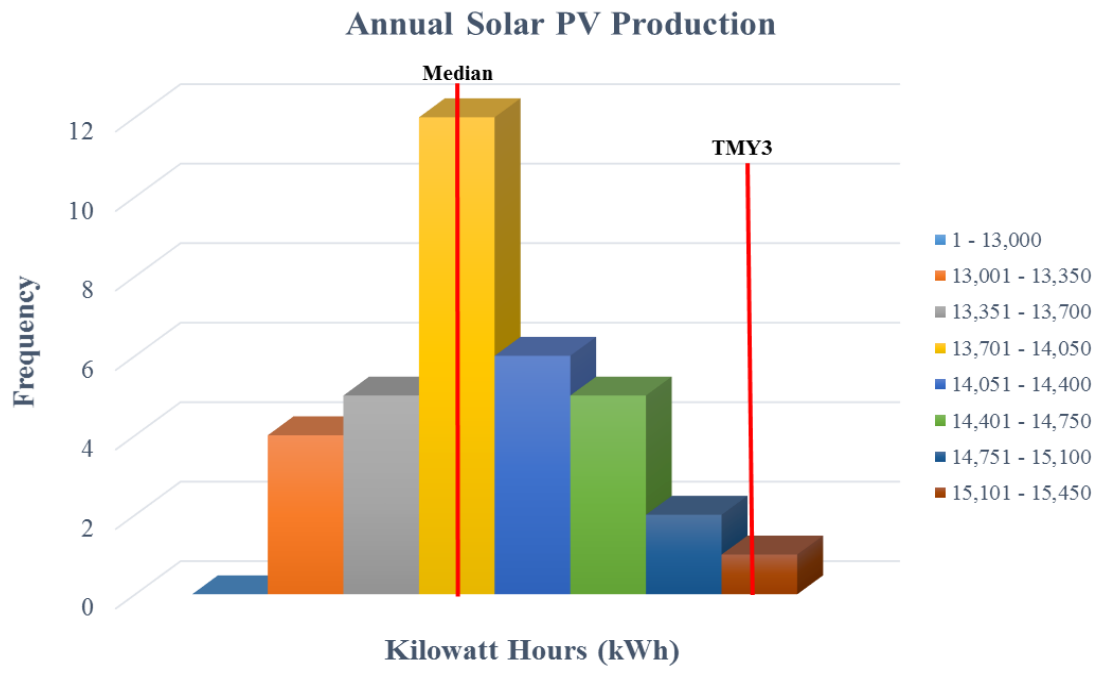

Figure 4-8: Histogram of Annual Solar PV Electricity Production for the TMY3 and AMY Files (1983 through 2013)

\subsection{Impacts of alternative weather profiles on annual net electricity production}

Sections 4.1 and 4.2 discussed the simulated responses of household consumption and production to different assumption of local weather conditions separately. This section will consider the impacts of alternative weather files on net electricity production or the excess electricity produced after household energy demands have been satisfied.

Net electricity production in this study is described as the difference between total electricity generated on-site and the total electricity consumed by the NZERTF each year. In Figure 4-9, the NZERTF not only achieves net-zero, but is also a net producer across all 34 AMY files. Similar to PV production, the rising trend line indicates that the home, on average, will increasingly become a net producer of energy over time. The simulated NZERTF design realizes the greatest excess production under 2001 weather conditions. Use of the 2001 weather file corresponds to the least amount of electricity consumption and the third largest level of PV production relative to all other simulations. The low annual consumption coupled with high annual production result in significant net production. Net production using the TMY3 file is higher than all but one AMY file. Data for the annual net production can be found in Table A-2 of the Appendix. 


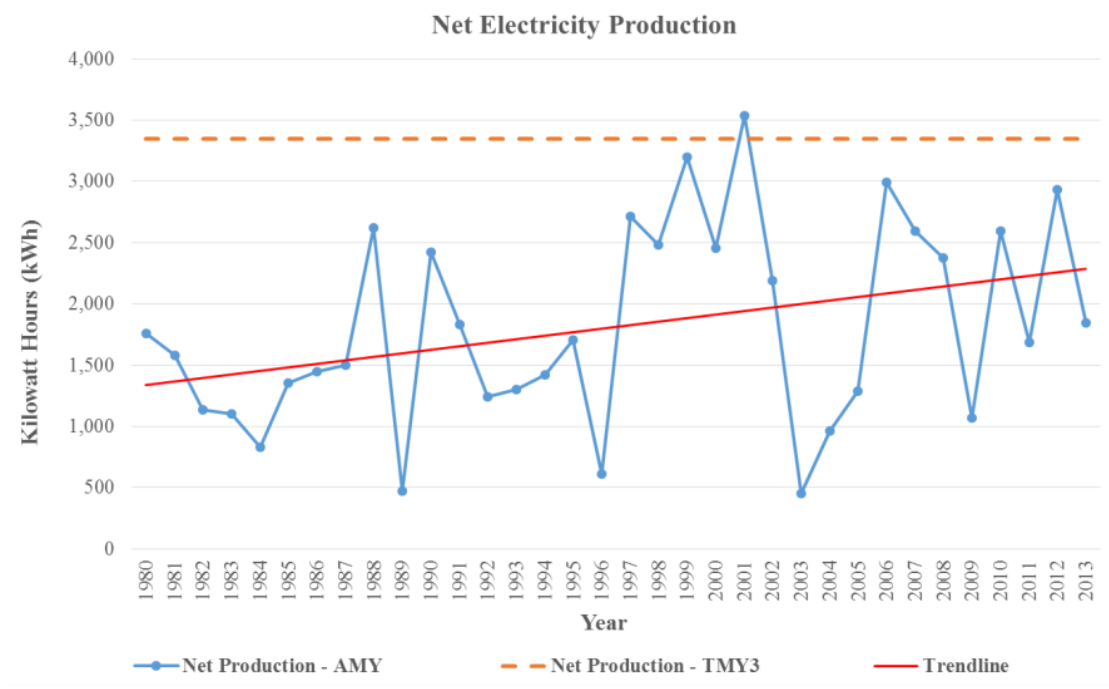

Figure 4-9: Annual Net Electricity Production for TMY3 and AMY Files (1980 through 2013)

The histogram of annual net production shown in Figure 4-10 shows that both the median and average ( $1815 \mathrm{kWh})$ net electricity production lie within the $1501 \mathrm{kWh}$ to $2000 \mathrm{kWh}$ bin range ${ }^{5}$. Like PV production, the likelihood that actual net production will be comparable to our TMY3 simulation is minimal based on where it lies within the distribution.

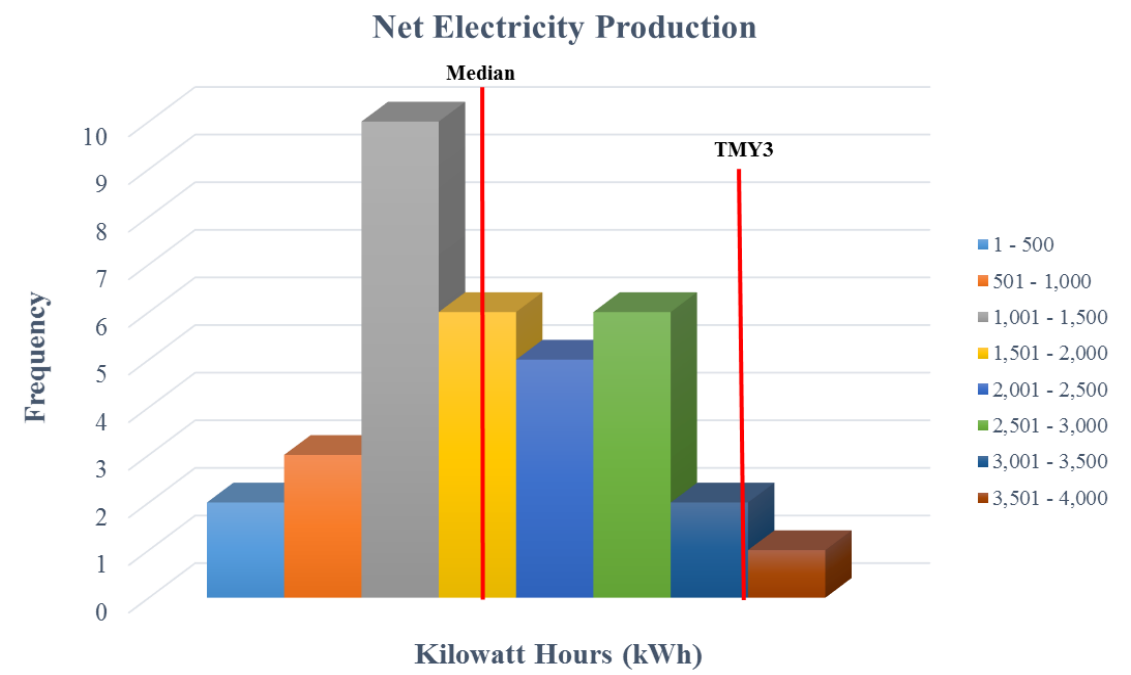

Figure 4-10: Histogram of Annual Net Electricity Production for the TMY3 and AMY Files (1983 through 2013)

\footnotetext{
${ }^{5}$ All calculated net production levels for the 34 simulations are unique - therefore, no mode exists.
} 


\subsection{Impacts of alternative weather profiles on building HVAC system peak electricity demands}

Annual peak electricity demands for the net-zero home's HVAC system are displayed in Figure $4-11^{6}$. Use of the TMY3 weather file can underestimate peak electricity demands by as much $69 \%(2059 \mathrm{~W})$, with only a slight overestimation of demand up to $1.7 \%(52 \mathrm{~W})$. The relationship between electricity demands and the number of HDDs and CDDs observed in Figure 4-4 - is more succinctly reflected in Figure 4-11. As the local climate grows warmer, particularly during the heating season, the household requires less electricity each year to heat the home. Despite increases in average cooling-based electricity demands, it is not enough to offset the average reductions in heating-based electricity, resulting in less annual electricity consumption related to use of the HVAC system over time. The negatively sloped trend line in Figure 4-11 suggests that average peak demands will level off as the local climate shifts towards being more cooling dominated and the annual electricity demands of the HVAC system decline.

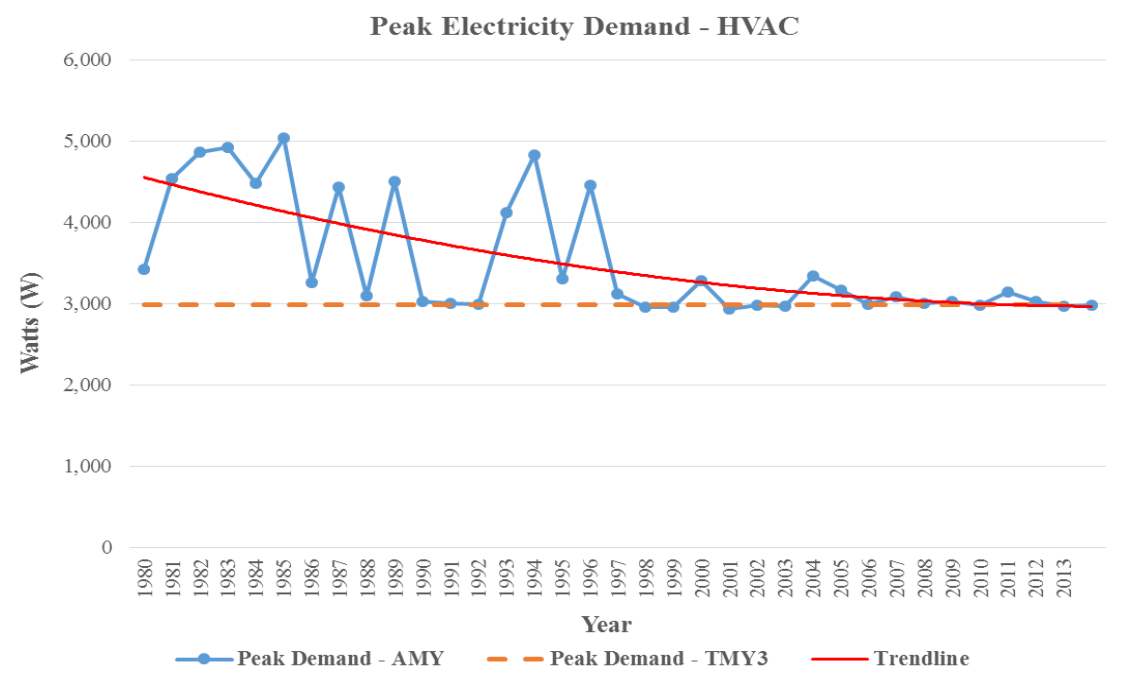

Figure 4-11: Annual Peak Electricity Demands for Building HVAC System

${ }^{6}$ Data for Figure 4-11 are listed in Table A-3 in the Appendix. 


\section{Conclusion}

This study seeks to expand upon existing literature by observing the variability in the energy performance of a net-zero energy residential building across 34 years of weather data specific to the Gaithersburg, MD area. In an effort to determine the likelihood that the Typical Meteorological Year 3 (TMY3) data is closely representative of "typical" weather conditions in the Gaithersburg area, we compare simulation results using the TMY3 data file to those simulations using actual historical data collected between 1980 and 2013.

Despite variation in annual household electricity use between $11300 \mathrm{kWh}$ and $12983 \mathrm{kWh}$ from year to year there is a consistent long-term average reduction in energy use of approximately $13 \mathrm{kWh}$ per year. Under assumptions of "typical" weather conditions, annual electricity use is roughly $11783 \mathrm{kWh}$ and lower than $76 \%$ of the measured consumption realized using the 34 AMY files. A majority of annual household energy usage is based on the heating and cooling needs of its occupants and is primarily dependent on external weather conditions. Therefore, any realized average consumption trends will be dependent on changes in the local climate. A slight reduction in the average number of annual HDDs combined with an average increase in the total number of CDDs from year to year suggests a shifting from a heating dominated climate towards a cooling dominated one. Additionally, homes built according to the NZERTF specifications in the area - which include equipment that is more efficient at cooling than heating - are likely to respond to the changing climate conditions by consuming less electricity. Given that total electricity usage falls well below average consumption in the case of TMY3 weather conditions, it is unlikely that the TMY3 file is appropriate for use in predicting typical annual household consumption.

Integrating the $10.2 \mathrm{~kW}$ solar PV system into the NZERTF design leads to annual generation of $13000 \mathrm{kWh}$ or more across all 35 weather files. Annual solar electricity generation is functional on yearly solar irradiance, where periods of higher solar irradiance coincide with greater production. Historical GHI measurements in the AMY files indicate marginal increases in local average solar radiation levels. Because solar electricity generation is functional on solar irradiance, it comes as no surprise that the simulated yearly NZERTF solar PV production follows a similar trend as rising GHI levels. The use of the KGAI TMY3 weather file in the simulation of the NZERTF results in a PV production more than $200 \mathrm{kWh}$ greater than when using any of the AMY weather files from previous years. Thus, use of this file in the future may overestimate that production, as well as generate other results that are not typical for that location as shown by historical data.

Measures of annual net electricity production provide insight into just how "net-zero" the NZERTF is under different assumptions of local weather conditions. Net production is greater than zero in all 35 cases and will likely become more of a net producer over time assuming equipment efficiencies increase and building parameters remain stable over time. Use of the TMY3 weather file causes an overestimation of net electricity production and, 
given its distance from both the average and median level of net production, it is not likely that net production simulated using the TMY3 data will accurately predict actual performance of the NZERTF.

Similar to total annual household electricity consumption, a less heating dominated climate leads to lower average peak electricity demands for the HVAC system. The "tighter" building envelope ensures that comfortable set point temperatures within the home are more likely to be sustained and that less electricity will be needed to heat it during periods of cold weather. Building simulations conducted based on assumptions of TMY3 weather conditions can significantly understate predicted peak demands.

Our findings highlight the importance of considering weather variability in the energy performance of net-zero building designs. Both determinants of a building being net-zero from year to year (energy consumption and production) are directly impacted by outside weather conditions. Any changes in annual local climatic conditions stand to influence a building's ability to be a net energy producer. As shown by our results, relying solely on TMY3 data to capture average weather conditions can produce results inconsistent with longterm historical averages. Decisions to leave out extreme weather anomalies along with a number of other factors when generating TMY3 weather files may cause files not to accurately capture average weather conditions for a given location. It is not to say that all TMY3 weather files will produce misleading results in all locations for all types of building designs. However, some consideration should be given for actual historical weather data when conducting building simulations and testing the robustness of the building's performance capabilities. Future research should consider alternative methods to developing representative weather data files, either through different statistical approaches to developing a TMY file or through multi-year simulation run periods. Also, alternative residential building designs and/or locations should be considered to determine if the results can be generalized to a broader range of scenarios. 


\section{References}

Building Science Corportation (BSC) (2009). "65\% Net-Zero Energy Residential Test Facility Construction Documents Set." 2012.

Cameron, C., et al. (2008). Comparison of PC System Performance-Model Predictions with Measured PV Performance. Conference Record of the IEEE Photovoltaic Specialists Conference, San Diego, CA.

Clarke, J. (2001). Energy Simulation in Building Design. London, Butterworth-Heinesmann.

Crawley, D., et al. (2000). "EnergyPlus: Energy Simulation Program." ASHRAE Journal 42(4): 49-56.

Crawley, D. B. (1998). "Which weather data should you use for energy simulations of commercial buildings?" Transactions-American Society of Heating, Refrigerating and AirConditioning Engineers 104: 498-515.

Dean, S. (2010). Quantifying the Variability of Solar PV Production Forecasts. Proceedings of the American Solar Energy Society SOLAR Natinoal Conference, Phoenix, AZ.

Donghyun, S., et al. (2010). "Impact of Typical Weather Year Selection Approaches on Energy Analysis of Buildings." ASHRAE Transactions 116(1): 416-427.

Energy Information Agency (EIA) (2015). "Consumption and Efficiency." Retrieved June 2014, from http://www.eia.gov/consumption/.

Ganguli, S. and J. Singh (2010). "Estimating the Solar Photovoltaic generation potential and possible plant capacity in Patiala." International Journal of Applied Engineering Research, Dindigul 1(2).

Haberl, J. S., et al. (1995). Impact of using measured weather data vs. TMY weather data in a DOE-2 simulation, American Society of Heating, Refrigerating and Air-Conditioning Engineers, Inc., Atlanta, GA (United States).

Hong, T., et al. (2013). "A Fresh Look at Weather Impact on Peak Electricity Demand and Energy Use of Buildings using 30-year Actual Weather Data." Applied Energy 111: 333-350. 
Hong, T., et al. (2013). A Sensitivity Study of Building Performance Using 30-year Actual Weather Data. 13th Conference of International Building Performance Simulation Association Chambéry, France.

Huang, J. (1998). The impact of different weather data on simulated residential heating and cooling load, American Society of Heating, Refrigerating and Air-Conditioning Engineers, Inc., Atlanta, GA (United States).

Huang, Y. and D. Crawley (1996). Does it Matter Which Weather Data You Use In Energy Simulations? American Council for an Energy Efficient Summer Study, Pacific Grove, CA.

Janjai, S. and P. Deeyai (2009). "Comparison of methods for generating typical meteorological year using meteorological data from a tropical environment." Applied Energy 86(4): 528-537.

Kneifel, J. (2011a). "Beyond the code: Energy, carbon, and cost savings using conventional technologies." Energy and Buildings 43(4): 951-959.

Kneifel, J. (2012). "Annual Whole Building Energy Simulation of the NIST Net Zero Energy Residential Test Facility Design." NIST Technical Note 1767.

Kneifel, J., et al. (2015). "Simulated versus Measured Energy Performance of the NIST Net Zero Residential Test Facility Design." NIST Special Publication 1182.

Leckner, M. and R. Zmeureanu (2011). "Life cycle cost and energy analysis of a Net Zero Energy House with solar combisystem." Applied Energy 88(1): 232-241.

Lstiburek, J. and P. Eng (2010). "Advanced Framing." Insight 30: 1-7.

Maile, T., et al. (2007). "Building energy performance simulation tools-a life-cycle and interoperable perspective." Center for Integrated Facility Engineering (CIFE) Working Paper 107: 1-49.

National Renewable Energy Laboratory (NREL) (1995). "User's Manual for TMY2s: Typical Meteorological Years." Retrieved 06/01/2015, 2015, from http://rredc.nrel.gov/solar/pubs/tmy2/PDFs/tmy2man.pdf.

National Renewable Energy Laboratory (NREL) (2008). "Users Manual for TMY3 Data Sets." Retrieved 06/01/2015, 2015, from http://www.nrel.gov/docs/fy08osti/43156.pdf. 
National Renewable Energy Laboratory (NREL) (2014). "Renewable Resource Data Center Glossary of Solar Radiation Resource Terms." Retrieved 06/17/20155, from http://rredc.nrel.gov/solar/glossary/otherlinks.html.

Pettit, B. and C. Gates (2014). "Design Challenges of the NIST Net Zero Energy Residential Test Facility." NIST Technical Note.

U.S. Department of Energy (DOE) (2015). EnergyPlus Simulation SoftwareVersion 8.3.0, Building Technologies Program (BTP).

USGBC Research Committee (2008). A National Green Building Research Agenda. Washington, DC, US Green Building Council.

Wang, L., et al. (2012). "Uncertainties in energy consumption introduced by building operations and weather for a medium-size office building." Energy and Buildings 53: 152-158.

Weather Analytics (2014). Actual Meteorological Year (AMY) Formatted Weather Data for July 1, 2013 through June 30,2014.

Weather Analytics (n.d.). What Are TMY and AMY Files: A Summary of Weather Files and Climate Data Input for Modelling. Silver Spring, MD.

Williams, M. and S. Kerrigan (2012). How Typical is Solar Energy? A 6 Year Evaluation of Typical Meteorological Data (TMY3). World Renewable Energy Forum, Denver, CO.

Yang, L., et al. (2008). "Building Energy Simulation using Multi-years and Typical Meteorological Years in Different Climates." Energy Conversion and Management 49(1): 113124.

Yimprayoon, C. and M. Navvab (2011). Impact of Differnt Weather Data Sets on Photovoltaic System Performance Evaluations. Proceeding of the Architectural Research Centers Consortium, Detroit, MI. 


\section{A Appendix}

Table A1: Annual Houshold Electricity Demands, Heating-based Electricity Demands, and Cooling-based Electricity Demands under each Weather File ${ }^{7}$

\begin{tabular}{|c|c|c|c|c|}
\hline $\begin{array}{l}\text { Weather } \\
\text { File }\end{array}$ & $\begin{array}{l}\text { Consumption } \\
\text { (kWh) }\end{array}$ & $\begin{array}{l}\text { Consumption - } \\
\text { Heating (kWh) }\end{array}$ & $\begin{array}{l}\text { Consumption - } \\
\text { Cooling (kWh) }\end{array}$ & $\begin{array}{c}\text { Consumption - } \\
\text { Other (kWh) }\end{array}$ \\
\hline 1980 & 12417 & 3342 & 2072 & 7003 \\
\hline 1981 & 12331 & 3364 & 1950 & 7017 \\
\hline 1982 & 12578 & 3272 & 2297 & 7009 \\
\hline 1983 & 12494 & 3156 & 2314 & 7024 \\
\hline 1984 & 12456 & 3011 & 2411 & 7034 \\
\hline 1985 & 12325 & 3108 & 2200 & 7017 \\
\hline 1986 & 12267 & 2972 & 2292 & 7003 \\
\hline 1987 & 12469 & 3006 & 2461 & 7002 \\
\hline 1988 & 12117 & 2989 & 2167 & 6961 \\
\hline 1989 & 12983 & 3278 & 2694 & 7011 \\
\hline 1990 & 11589 & 2169 & 2431 & 6989 \\
\hline 1991 & 12031 & 2489 & 2542 & 7000 \\
\hline 1992 & 11925 & 2808 & 2081 & 7036 \\
\hline 1993 & 12403 & 3089 & 2303 & 7011 \\
\hline 1994 & 12464 & 3078 & 2372 & 7014 \\
\hline 1995 & 12439 & 3056 & 2386 & 6997 \\
\hline 1996 & 12817 & 3381 & 2414 & 7022 \\
\hline 1997 & 11656 & 2794 & 1867 & 6995 \\
\hline 1998 & 11500 & 2114 & 2383 & 7003 \\
\hline 1999 & 11500 & 2406 & 2125 & 6969 \\
\hline 2000 & 11717 & 2775 & 1958 & 6984 \\
\hline 2001 & 11300 & 2267 & 2064 & 6969 \\
\hline
\end{tabular}

\footnotetext{
7 “Consumption - Other" includes all other electricity consumption, including DHW, plug loads and appliances, and lighting.
} 


\begin{tabular}{|c|c|c|c|c|}
\hline 2002 & 11783 & 2400 & 2408 & 6975 \\
\hline 2003 & 12597 & 2969 & 2603 & 7025 \\
\hline 2004 & 12603 & 2739 & 2856 & 7008 \\
\hline 2005 & 12417 & 2769 & 2658 & 6990 \\
\hline 2006 & 11492 & 2008 & 2511 & 6973 \\
\hline 2007 & 12106 & 2650 & 2483 & 6973 \\
\hline 2008 & 11800 & 2444 & 2353 & 7003 \\
\hline 2009 & 12228 & 2742 & 2475 & 7011 \\
\hline 2010 & 12339 & 2817 & 2569 & 6953 \\
\hline 2011 & 12275 & 2389 & 2900 & 6986 \\
\hline 2012 & 11561 & 2044 & 2550 & 6967 \\
\hline 2013 & 12367 & 2703 & 2686 & 6978 \\
\hline TMY3 & 11783 & 1733 & 3108 & 6942 \\
\hline
\end{tabular}


Table A2: Annual Houshold Electricity Demands, Solar PV Production, and Net Solar PV Production under each Weather File

\begin{tabular}{|c|c|c|c|}
\hline Weather File & $\begin{array}{l}\text { Electricity Consumption } \\
\text { (kWh) }\end{array}$ & $\begin{array}{l}\text { PV Production } \\
\text { (kWh) }\end{array}$ & $\begin{array}{l}\text { Net Production } \\
(\mathbf{k W h})\end{array}$ \\
\hline 1980 & 12417 & 14175 & 1758 \\
\hline 1981 & 12331 & 13911 & 1581 \\
\hline 1982 & 12578 & 13714 & 1136 \\
\hline 1983 & 12494 & 13600 & 1106 \\
\hline 1984 & 12456 & 13283 & 828 \\
\hline 1985 & 12325 & 13678 & 1353 \\
\hline 1986 & 12267 & 13711 & 1444 \\
\hline 1987 & 12469 & 13967 & 1497 \\
\hline 1988 & 12117 & 14739 & 2622 \\
\hline 1989 & 12983 & 13456 & 472 \\
\hline 1990 & 11589 & 14014 & 2425 \\
\hline 1991 & 12031 & 13861 & 1831 \\
\hline 1992 & 11925 & 13164 & 1239 \\
\hline 1993 & 12403 & 13703 & 1300 \\
\hline 1994 & 12464 & 13886 & 1422 \\
\hline 1995 & 12439 & 14142 & 1703 \\
\hline 1996 & 12817 & 13425 & 608 \\
\hline 1997 & 11656 & 14372 & 2717 \\
\hline 1998 & 11500 & 13983 & 2483 \\
\hline 1999 & 11500 & 14697 & 3197 \\
\hline 2000 & 11717 & 14169 & 2453 \\
\hline 2001 & 11300 & 14836 & 3536 \\
\hline 2002 & 11783 & 13975 & 2192 \\
\hline 2003 & 12597 & 13053 & 456 \\
\hline 2004 & 12603 & 13564 & 961 \\
\hline
\end{tabular}




\begin{tabular}{|c|c|c|c|}
\hline 2005 & 12417 & 13703 & 1286 \\
\hline 2006 & 11492 & 14483 & 2992 \\
\hline 2007 & 12106 & 14703 & 2597 \\
\hline 2008 & 11800 & 14178 & 2378 \\
\hline 2009 & 12228 & 13297 & 1069 \\
\hline 2010 & 12339 & 14931 & 2592 \\
\hline 2011 & 12275 & 13964 & 1689 \\
\hline 2012 & 11561 & 14492 & 2931 \\
\hline 2013 & 12367 & 14214 & 1847 \\
\hline TMY3 & 11783 & 15131 & 3347 \\
\hline
\end{tabular}


Table A3: Peak Electricity Demands for the Building HVAC System under each Weather File

\begin{tabular}{|c|c|}
\hline Weather File & Peak Electricity Demand (W) \\
\hline 1980 & 3423 \\
\hline 1981 & 4541 \\
\hline 1982 & 4857 \\
\hline 1983 & 4925 \\
\hline 1984 & 4481 \\
\hline 1985 & 5041 \\
\hline 1986 & 3259 \\
\hline 1987 & 4428 \\
\hline 1988 & 3099 \\
\hline 1989 & 4500 \\
\hline 1990 & 3028 \\
\hline 1991 & 3004 \\
\hline 1992 & 2993 \\
\hline 1993 & 4120 \\
\hline 1994 & 4832 \\
\hline 1995 & 3299 \\
\hline 1996 & 4461 \\
\hline 1997 & 3117 \\
\hline 1998 & 2959 \\
\hline 1999 & 2956 \\
\hline 2000 & 3278 \\
\hline 2001 & 2931 \\
\hline 2002 & 2976 \\
\hline 2003 & 2966 \\
\hline 2004 & 3341 \\
\hline 2005 & 3170 \\
\hline
\end{tabular}




\begin{tabular}{|cc|}
\hline $\mathbf{2 0 0 6}$ & 2986 \\
\hline $\mathbf{2 0 0 7}$ & 3079 \\
\hline $\mathbf{2 0 0 8}$ & 3005 \\
\hline $\mathbf{2 0 0 9}$ & 3030 \\
\hline $\mathbf{2 0 1 0}$ & 2978 \\
\hline $\mathbf{2 0 1 1}$ & 3139 \\
\hline $\mathbf{2 0 1 2}$ & 3024 \\
\hline $\mathbf{2 0 1 3}$ & 2962 \\
\hline TMY 3 & 2983 \\
\hline
\end{tabular}

